\title{
Analytical Study of Phytochemicals and Antioxidant Activity of Pollen (Typha Domingensis Pers.) Extracted from The Papyrus Plant and Its Use in Cake Enrichment
}

\author{
Nareman Adeem Shnaa Aljazy ${ }^{\text {a) }}$, Alaa R. Abdulstar ${ }^{\text {b) }}$ and Jinan Mohammed Fayyad Alrakabi \\ Department of Food Science, College of Agriculture, University of Basrah, Iraq. \\ a) nareman.shnaa@uobasrah.edu.iq \\ b) Corresponding Author: alaa.abdull_sattar@uobasrah.edu.iq
}

Received : 2/12/2021
Acceptance : 29/12/2021
Available online: $31 / 12 / 2021$

\begin{abstract}
The pollen (typha domingensis pers.) of the papyrus plant is one of the foods rich in minerals and active chemical compounds, known for its important properties. This study came to determine those chemical compounds and the possibility of including pollen in the development of suitable cake formulations. The active compounds in the three pollen extracts (aqueous, ethanol, and hexane) were determined by gas chromatography connected to a mass spectrometer (GCMS), The total content of flavonoids and the antioxidant activity by free radicals DPPH was estimated by hydrogen donation for all chemical extracts, The mineral elements were estimated by Inductively Coupled Plasma Mass Spectrometry (ICP-MS) as well as studying the sensory properties of pollen cake. The results showed that pollen contains many active compounds such as gamma.sitosterol, catechol, propionic acid, phenols and palmitoleic acid. The highest total flavonoids content was at the concentration of $75 \mathrm{mg} / \mathrm{ml}$, as it ranged between 99 $\mathrm{mg} / \mathrm{ml}$ for the ethanolic extract and $98 \mathrm{mg} / \mathrm{ml}$ for the aqueous and hexane extract. The pollen extracts showed that they had a good ability to inhibit free radical DPPH by donating hydrogen, the results showed that there were no significant differences in the percentage of inhibition of the extracts, which amounted to $83 \%, 79 \%$ and $76 \%$ for hexane ,ethanol and aqueous extracts at a concentration of $75 \mathrm{mg} / \mathrm{ml}$. The results showed that the pollen contained a good content of calcium, potassium, magnesium and zinc, which amounted to $(19.794,23.620,4.578$ and 0.08$) \mathrm{g} / \mathrm{L}$, respectively. Sensory evaluation also showed excellent potential of pollen when used as a functional ingredient in cake making.
\end{abstract}

Keywords. Unique Cake, Antioxidants, Bardy pollen, Active compounds.

\section{INTRODUCTION}

Bardy (papyrus), also known as cattail, It is a long -stemmed perennial plant with spear -shaped leaves that belongs to the typhaceae family. It is iconic marsh plants in basrah, southern Iraq. Bardy pollen (typha domingensis pers.) is a high energy nutritional material rich in vitamins, minerals and active compounds such as phenols and flavonoids, known for its free radical scavenging properties and protecting our bodies from oxidative damage, the most cause of many diseases . Flavonoids are the most important among many of the antioxidant compounds and it also contributes to the antimicrobial properties of pollen [1]. Bardy (typha domingenisis pers) is a concentrated phytonutrients that has antioxidant properties and powerful potential for treating mercury - contaminated water [2]. Studies have paid great attention to pollen in the remedies of polluted wastewaters as it is a low cost environmentally friendly and highly effective technique in absorbing heavy metal ions and accumulating them in the roots and leaves [3]. Papyrus pollen is used as a therapeutic agent to chelate excess iron in the body which causes oxidative stress which is the main factor in many diseases such as neurodegenerative and cancer [4] . Papyrus pollen is an important source of natural antioxidants and phenolic compounds that possess glucosidase inhibitor activity .Glucosidase inhibitors represent the first line of remedy for type 2 diabetes patients. These inhibitors can impede glucose absorption in the small intestine, thus reducing the rise in blood glucose [5]. It is always mentioned that the antioxidants in our body help neutralize the free radicals and prevent them from causing harmful effects and this promotes overall health .From a nutritional point of view, various plant substances such as beta-carotene, vitamin C. phenols and flavonoids prevent oxidative reactions catalyzed by oxygen and peroxides. In addition, antioxidants in general and flavonoids in particular play a vital role in food preservation technology. Flavonoids are water -soluble, golden -yellow pigments. They are powerful antioxidants that sacrifice their electrons to free radicals and make them more stable, thus inhibiting the chain of oxidative reactions that end in damage to the food composition or spoilage and formation of unacceptable flavors [6], and that flavonoids and phenolic compounds are the most important chemical compounds and to which many unique properties of pollen are attributed. In the Mesopotamian marshes, specifically in Basrah and Maysan , 
Bardy - cattail typha domingensis pers.( the source of pollen ) grows automatically and pollen contains many biologically active compounds such as alkaloids, tannins, saponins glycosides and flavonoids [7] .In addition, typha domingensis was dominates on the warm wetlands of Florida in the south of the United States of America [8]. Pollen is also called the marsh treasure or yellow gold, as it was introduced into the food industry as a sweetener substance and is also used in the production of delicious sweets called "Khairat". It is a therapeutic food substances famous for its manufacture in the marshlands by collecting pollen grains from spikes and then putting it on a mat under the sun's rays .After that, the process of steam cooking is done after mixing it with a small amount of sugar and placing it in a specialized cloth at the top of a container containing water and when exposed to water vapour it becomes agglomerated, then it is broken into small pieces and sold, and there is a strong demand for its purchase [9]. Pollen has been widely introduced into the food industry . Historically, pollen consumption dates back to 1933 and 1911 . In china and southern Iraq, pollen was combined with honey and sold as a candy[10]. In addition, The marshes of Iraq and Iran are also the original source of typha pollen . Typha pollen is a life-giving food, rich in antioxidants and potent plant compounds. The flavonoids in pollen not only give the nutritional value of the food only, but also give distinctive golden colors to the products included in its composition . There is also another advantage of food pollen derivatives, which is that they are free of gluten. Therefore, it is perfectly suitable for patients who suffer from disorders and health problems due to gluten sensitivity, and that improving their health depends mainly on reducing gluten in their lifestyle. Researchers have paid great attention to special products to meet their requirements $[11,12]$. The aim of this study was to evaluate the antioxidant activity of pollen extracts and to develop suitable Partial replacement of gluten cake formulations for patients with gluten sensitivity by substituting wheat flour for pollen flour to obtain high-quality products from a nutritional and sensory point of view, As well as reviving traditional knowledge and studying it scientifically to enrich this agricultural treasure and make it more appreciated.

\section{MATERIALS AND METHODS}

\section{- Material of Pollen Papyrus}

Pollen flour typha domingensis pers. was purchased from the popular markets in Basrah governorate, southern Iraq.

\section{- Preparation of Pollen Papyrus Extracts}

Pollen ethanolic, aqueous and hexane extract prepared by weighing $10 \mathrm{~g}$ of pollen powder with $100 \mathrm{ml}$ ethanol solution ( $800 \mathrm{ml} /$ liter of distilled water), then the mixture was placed in a shaking incubator at $40 \mathrm{C}$, Then use a quality paper to filter the extract and then rotary evaporator until the extract is completely dry, it is kept at $4{ }^{\circ} \mathrm{C}$ until testing [13] .

\section{- Diagnostics of Active Compounds Using Mass Spectrometry Gas Chromatography}

The active compounds in pollen extracts identified by a gas chromatograph connected to a Mass Spectrometer, GC-MS analysis was carried out at the Basra oil company Laboratory, by using an Agilent Technologies, 7890B GC system coupled to an Agilent Technologies 5977A MSD with EI Signal detector, using HP-5ms 5\% phenyl, 95\% methyl siloxane $(30 \mathrm{~m} * 250 \mathrm{um} * 0.25)$, the oven temperature was set at $40 \mathrm{C}$ hold for $5 \mathrm{~min}$ then raised to $10 \mathrm{C} / \mathrm{min}$ to $300 \mathrm{C}$ for $20 \mathrm{~min}$, Helium carrier gas flow rate was $1 \mathrm{ml} / \mathrm{min}$ and purge flow of $3 \mathrm{ml} / \mathrm{min}$. The injection mode was pulsed Split less with injection temperature $290 \mathrm{C}$ and the injection sample volume was 1 micro letter. The mass spectrometer used Ion Source Temperature $230 \mathrm{C}$, With scan speed $1562\left(\mathrm{~N}_{2}\right)$, and the mass range $44-750 \mathrm{~m} / \mathrm{z}$, Data was run through the NIST 2014 , and Wiley 9 Library data base as an additional tool to confirm identity of compounds.

\section{- Metal Detection Using ICP-OES OPTIMA 8300 Perkinelmer (Inductively Coupled Plasma Optical Emission Spectroscopy)}

The mineral elements in pollen powder were estimated by ICP-OES OPTIMA 8300 DV ( Perkin-Elmer, Waltham, Massachusetts, USA) in accordance with [14], The sample was diluted 20 once before the measurement process.

\section{- Gluten Test}

Gluten test was performed according to [15] , $25 \mathrm{~g}$ of pollen flour weighed and $15 \mathrm{ml}$ of water was added to it and kneaded into a ball that was placed in a glass of water for an hour and then the ball washed under a stream of calm water until the starch was removed, after which the percentage of residual gluten was calculated by the following relationship

$$
\text { Percentage of residual gluten } \%=\frac{\text { Weight of the remaining dough }}{\text { Total sample weight }} \times 100
$$




\section{- Determination of The Amount of Flavonoids}

A method followed $[16,17]$. For the determination of flavonoids in aqueous, alcoholic and hexane pollen extracts by dissolving $8.5,12.5,25,50,75 \mathrm{mg} / \mathrm{ml}$. Also , the rutin standard solution was prepared in ethanol with concentrations from 10 to $160 \mathrm{mg} / \mathrm{ml}$, and depending on the graphic relationship between rutin concentration and absorbance at a wavelength $430 \mathrm{~nm}$, The amount of flavonoids in the extracts was calculated by drawing the standard curve between the absorbance reading for each concentration of rutin to get the straight line equation through which the amount of flavonoids in pollen extracts was calculated .

\section{- DPPH Radical Scavenging Assay (DPPH . RSA)}

The ability of typha pollen to scavenge free radical DPPH (2,2 Diphenyl-1-picryl-hydrazyl) was measured by reacting $0.5 \mathrm{ml}$ of pollen extract $(8.5,12.5,25,50,75 \mathrm{mg} / \mathrm{ml})$ with $0.3 \mathrm{ml}$ of ethanol with $0.3 \mathrm{ml}(0.5 \mathrm{mM} \mathrm{DPPH}$, and the mixture was incubated at 45 minutes at room temperature , after which the absorbance was read at $517 \mathrm{~nm}$ using a spectrophotometer [18] ,Then it calculated by the following relationship: $\{1-$ [Abs sample / Abs control ] $\} \times 100$

\section{- Manufacture of Pollen Cake}

The cake mix was prepared in an electric mixer with the addition of eggs, oil ,milk, backing powder, sugar, then placed in a preheated electric oven at a temperature of $180 \mathrm{C}$ for 40 minutes. The mixture prepared with wheat flour without pollen (sample A) as control, and (sample B )by replacing 50\% of the wheat flour with gluten-free pollen flour and pollen grains occupied in the third sample $\mathrm{C} 75 \%$. The sensory and structural evaluation of the cake was conducted through the sensory acceptance form, which consisted of 5 qualitative characteristics, namely color, texture ,appearance ,odor and taste , with the participation of 100 tasters and depending on what they prefer [19].

\section{- Statistical Analysis}

The Statistical Package of Social Sciences (SPSS) software package (version 26.0) was used to analyze all scientific experiment data in three replicates and the data were evaluated using one-way ANOVA and the results were considered statistically significant at $(\mathrm{p}<0.05)$.

\section{RESULTS AND DISCUSSION}

\section{- Diagnostics of Active Compounds in Gas Chromatography-Mass Spectrometry}

All extracts contained many bioactive compounds that identified by GC-MS and differenced in their percentage according to the type of solvent. All extracts share with some bioactive compound as, gamma .sitosterol, catechol, propionic acid, phenols, palmitoleic acid. The results show the appearance of 49 peaks representing the active compounds in the aqueous extract of pollen, as the compound n-Hexadecaneoic acid appeared with a percentage of $14.16 \%$ at the peak 38 and a retention time 23.724 , followed by the compound 2,3,1-Benzodiazaborine ,1,2-dihydrro-1-methyl at a percentage of 8.7005 in the peak 25 and with a retention time of 14.045. The results diagnosed with GC -Mass revealed the dominance of the following active compounds in ethanolic extracts : linolaidic acid with a percentage of $38.2431 \%$ in the peak 16 and a retention time of 25.343 , as well as the compound n-hexadecanoic acid with a percentage $22.9509 \%$ at the peak 15 and a retention time of 23.681 , while other classes of compounds contributed small percentage, such as gamma -sitosterol $2.6354 \%$ at the peak 23 and catechol by $1.0231 \%$ at the peak 11, As for the hexane extract, appeared 23 peaks , and the 9,12 octadecandienoic acid z-z compound occupied the highest percentage of $40 \%$ at the peak 17.

TABLE 1. Active compounds present in the aqueous extract.

\begin{tabular}{ccccc}
\hline Peak & R.Time & Area & Area Pct. & Compound \\
\hline 1 & 4.819 & 3167129 & 0.5699 & Ethyl aminomethylformimidate \\
2 & 5.332 & 1900134 & 0.3419 & 3H-Pyrazol-3-one, 1,2-dihydro-5-methyl \\
3 & 6.217 & 3807699 & 0.6852 & Pyridine \\
4 & 6.576 & 826398 & 0.1487 & 2-Butanone, 4-hydroxy-3-methyl \\
5 & 7.023 & 9521448 & 1.7133 & 1-Octen-3-ol \\
6 & 7.389 & 44758518 & 8.054 & Hexanal, 2-ethyl \\
7 & 8.634 & 936891 & 0.1686 & 6-Methyl-2-pyridinecarbaldehyde \\
8 & 8.7 & 819825 & 0.1475 & 4,4,6-Trimethyl-3,7,9-trioxabicyclo[4.2.1]nonane \\
\hline
\end{tabular}




\begin{tabular}{|c|c|c|c|c|}
\hline Peak & R.Time & Area & Area Pct. & Compound \\
\hline 9 & 9.681 & 14471655 & 2.6041 & Furan, tetrahydro-3-methyl \\
\hline 10 & 10.45 & 4366110 & 0.7857 & 2-Furancarboxaldehyde, 5-methyl \\
\hline 11 & 11.006 & 1765453 & 0.3177 & Formic acid phenyl ester \\
\hline 12 & 11.284 & 18551422 & 3.3382 & 1,4-Benzenediamine, 2-methyl \\
\hline 13 & 11.929 & 25655677 & 4.6166 & Benzeneacetaldehyde \\
\hline 14 & 12.038 & 7287226 & 1.3113 & Cyclohexanol, 2,6-dimethyl \\
\hline 15 & 12.163 & 2386550 & 0.4294 & 1-Hexyne, 5-methyl \\
\hline 16 & 12.302 & 1548038 & 0.2786 & 2-Nonanone \\
\hline 17 & 12.588 & 4001483 & 0.72 & Propanoic acid, 2-mercapto-2-methyl \\
\hline 18 & 12.712 & 15460973 & 2.7821 & Pyrazine, 3-ethyl-2,5-dimethyl \\
\hline 19 & 13.005 & 18553173 & 3.3385 & Furaneol \\
\hline 20 & 13.115 & 3125620 & 0.5624 & 2,3-Pentadienoic acid-, ethyl ester \\
\hline 21 & 13.452 & 3006238 & 0.541 & 6,8-Dioxabicyclo[3.2.1] octan-4-one, oxime \\
\hline 22 & 13.591 & 1623152 & 0.2921 & 1H-Azonine, octahydro \\
\hline 23 & 13.664 & 1887006 & 0.3396 & Decanal dimethyl acetal \\
\hline 24 & 13.737 & 3938253 & 0.7087 & endo-2-Aminonorbornane \\
\hline 25 & 14.045 & 48351082 & 8.7005 & 2,3,1-Benzodiazaborine, 1,2-dihydro-1-methyl \\
\hline 26 & 14.704 & 10019071 & 1.8029 & Hexane, 2,3,4-trimethyl \\
\hline 27 & 15.509 & 32504725 & 5.849 & 1,3-Propanediamine, N,N-dimethyl \\
\hline 28 & 16.066 & 6577011 & 1.1835 & N-Formyl-dl-alpha-aminobutyric acid \\
\hline 29 & 16.227 & 1736020 & 0.3124 & 3,4-Diethylphenol \\
\hline 30 & 16.3 & 10785951 & 1.9409 & Pyrazine, 2,5-dimethyl-3-(3-methylbutyl) \\
\hline 31 & 16.966 & 5055730 & 0.9097 & Piperidine, 1-methyl \\
\hline 32 & 18.365 & 8697530 & 1.5651 & Pyridine, 2-phenyl \\
\hline 33 & 19.719 & 5883398 & 1.0587 & 4-Pyridinamine, 2,6-dimethyl \\
\hline 34 & 21.865 & 6647628 & 1.1962 & Bicyclo[2.2.1]hept-2-ene, 2-methyl \\
\hline 35 & 22.831 & 12898671 & 2.321 & 2H-imidazole-2-thione, 1,3-dihydro-4-(2-methylpropyl) \\
\hline 36 & 23.475 & 13996811 & 2.5186 & Benzoic acid, 3,5-dihydroxy \\
\hline 37 & 23.636 & 11558239 & 2.0798 & Pyrrolo[1,2-a]pyrazine-1,4-dione, hexahydro-3-(2-methylpropyl) \\
\hline 38 & 23.724 & 78693531 & 14.1604 & n-Hexadecanoic acid \\
\hline 39 & 24.105 & 5341557 & 0.9612 & 9H-Pyrido[3,4-b]indole, 1-methyl \\
\hline 40 & 25.328 & 30531092 & 5.4939 & 9,12-Octadecadienoic acid $(\mathrm{Z}, \mathrm{Z})$ \\
\hline 41 & 26.089 & 7247423 & 1.3041 & 9,12-Octadecadienoic acid $(\mathrm{Z}, \mathrm{Z})$ \\
\hline 42 & 26.697 & 24840018 & 4.4698 & Hexadecane, 2,6,10,14-tetramethyl \\
\hline 43 & 27.056 & 8997464 & 1.619 & 9-Octadecyne \\
\hline 44 & 28.315 & 11768422 & 2.1177 & Heptadecane \\
\hline 45 & 29.824 & 2555750 & 0.4599 & Eicosane \\
\hline 46 & 31.09 & 5994870 & 1.0787 & Nonacos-1-ene \\
\hline 47 & 32.664 & 2681609 & 0.4825 & Fumaric acid, pent-4-en-2-yl tridecyl ester \\
\hline 48 & 32.921 & 4522551 & 0.8138 & Fumaric acid, pent-4-en-2-yl tridecyl ester \\
\hline 49 & 35.71 & 4477175 & 0.8056 & gamma.-Sitosterol \\
\hline
\end{tabular}




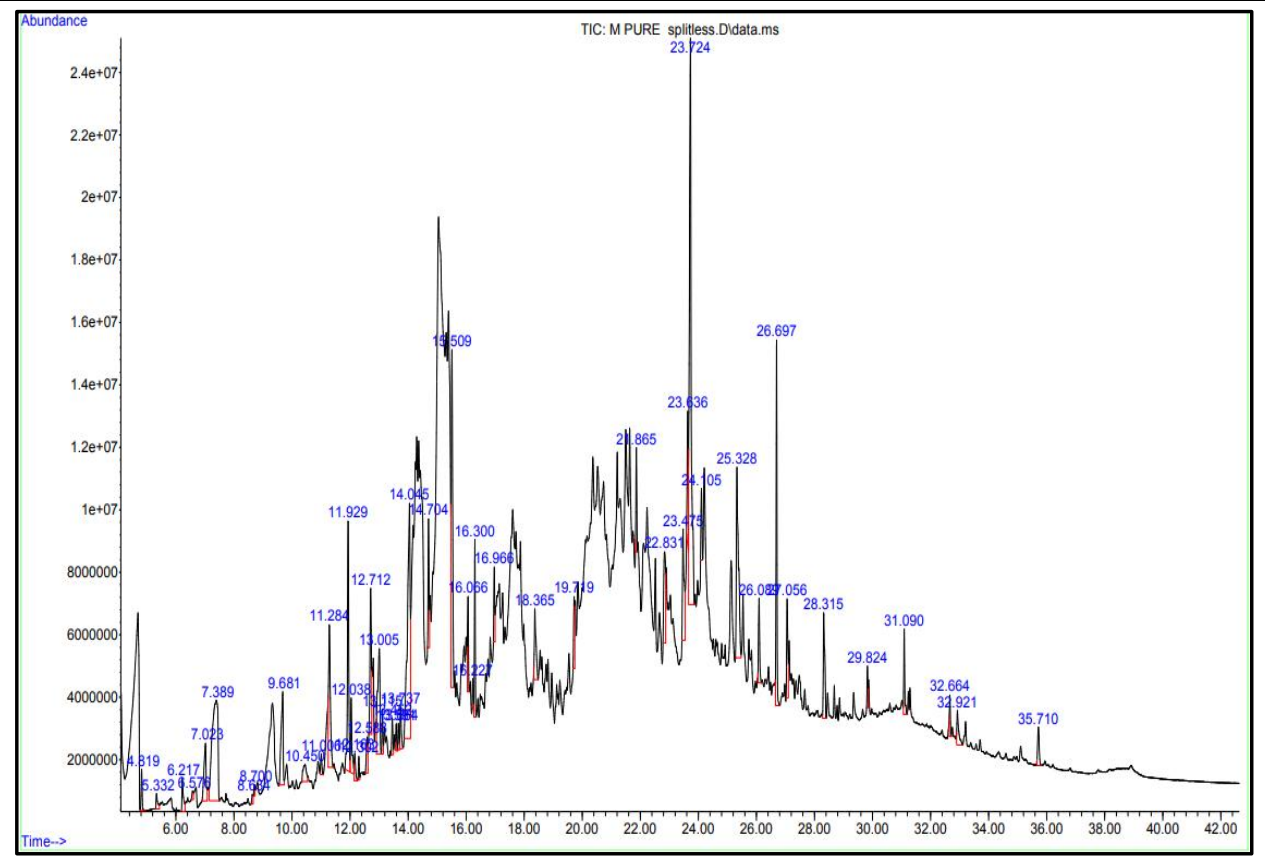

FIGURE 1. Active compounds present in the aqueous extract.

TABLE 2. Active compounds present in the ethanolic extract.

\begin{tabular}{|c|c|c|c|c|}
\hline Peak & R.Time & Area & Area Pct. & Compound \\
\hline 1 & 5.947 & 8961302 & 2.2677 & Methylamine, N,N-dimethyl \\
\hline 2 & 6.276 & 2318977 & 0.5868 & Acetamide, oxime \\
\hline 3 & 6.364 & 9578522 & 2.4239 & Urea, methyl \\
\hline 4 & 7.697 & 3908906 & 0.9892 & 3,5-Dimethylpyrazole \\
\hline 5 & 10.01 & 3301952 & 0.8356 & 3-Azabutyl-1-ol, O-acetyl-4-cyclopropyl-N,N-dimethyl-, bromide \\
\hline 6 & 11.482 & 26632860 & 6.7396 & Pentanal, 2,4-dimethyl \\
\hline 7 & 11.826 & 2735827 & 0.6923 & 3-Methylcyclopentane-1,2-dione \\
\hline 8 & 12.493 & 8738986 & 2.2115 & 2,5-Dimethylfuran-3,4(2H,5H)-dione \\
\hline 9 & 12.785 & 2994154 & 0.7577 & Mequinol \\
\hline 10 & 12.99 & 2603621 & 0.6589 & Hexanal, 2-ethyl \\
\hline 11 & 14.748 & 4042868 & 1.0231 & Catechol \\
\hline 12 & 15.143 & 6695583 & 1.6944 & 5-Hydroxymethylfurfural \\
\hline 13 & 17.706 & 2036356 & 0.5153 & 2,6-Difluoro-.alpha.-methylbenzyl alcohol, acetate \\
\hline 14 & 21.557 & 2221674 & 0.5622 & Tetradecanoic acid \\
\hline 15 & 23.681 & 90694498 & 22.9509 & n-Hexadecanoic acid \\
\hline 16 & 25.343 & 15112457 & 38.2431 & Linoelaidic acid \\
\hline 17 & 25.526 & 6409083 & 1.6219 & Octadecanoic acid \\
\hline 18 & 25.723 & 5857163 & 1.4822 & 9,12-Octadecadienoic acid (Z,Z) \\
\hline 19 & 26.06 & 4188473 & 1.0599 & 9,12-Octadecadienoic acid (Z,Z) \\
\hline 20 & 27.034 & 9432822 & 2.387 & Z-1,6-Tridecadiene \\
\hline 21 & 28.454 & 11153924 & 2.8226 & Hexadecanoic acid, 2-hydroxy-1-(hydroxymethyl)ethyl ester \\
\hline 22 & 29.831 & 16934382 & 4.2854 & 9,12-Octadecadienoic acid (Z,Z)-, 2,3-dihydroxypropyl ester \\
\hline 23 & 35.711 & 10414108 & 2.6354 & .gamma.-Sitosterol \\
\hline 24 & 35.937 & 2187171 & 0.5535 & Tris(tert-butyldimethylsilyloxy)arsane \\
\hline
\end{tabular}




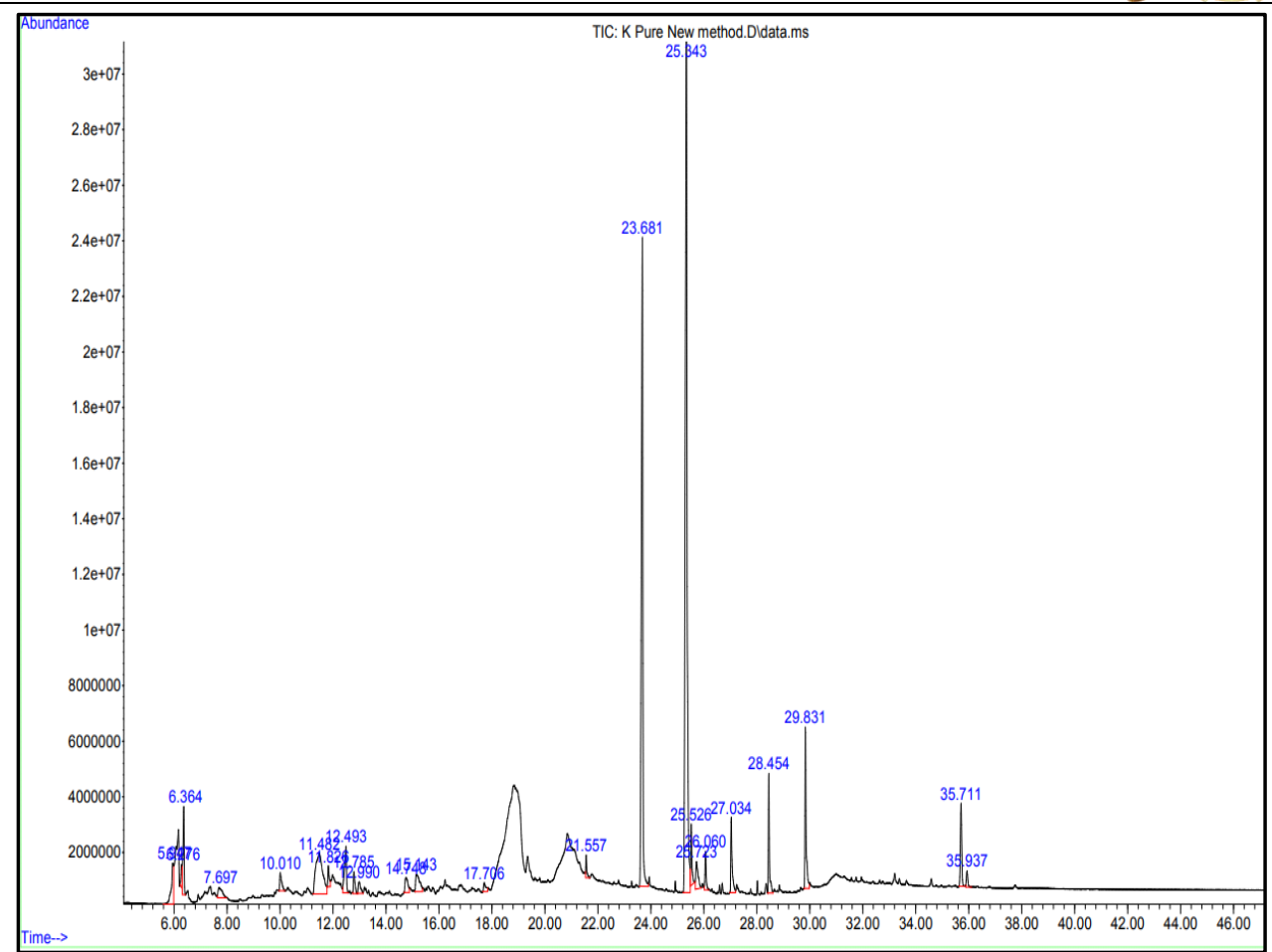

FIGURE 2. Active compounds present in the ethanolic extract.

TABLE 3. Active compounds present in the hexane extract.

\begin{tabular}{|c|c|c|c|c|}
\hline Peak & R.Time & Area & Area Pct. & Compound \\
\hline 1 & 5.8 & 4077538 & 1.2788 & Methylamine, N,N-dimethyl \\
\hline 2 & 6.005 & 3288122 & 1.0313 & Hydrazine, 1,1-dimethyl \\
\hline 3 & 6.218 & 4927581 & 1.5454 & N-Nitrosodimethylamine \\
\hline 4 & 6.305 & 8676767 & 2.7213 & Urea, methyl \\
\hline 5 & 6.488 & 2370343 & 0.7434 & Propanoic acid \\
\hline 6 & 7.067 & 1349955 & 0.4234 & N-Methylpivalamide \\
\hline 7 & 9.944 & 2828595 & 0.8871 & 3-Azabutyl-1-ol, O-acetyl-4-cyclopropyl-N,N-dimethyl-, bromide \\
\hline 8 & 11.402 & 21472513 & 6.7344 & Butane, 1,4-dimethoxy \\
\hline 9 & 11.797 & 2556883 & 0.8019 & 2-Cyclopenten-1-one, 2-hydroxy-3-methyl \\
\hline 10 & 12.471 & 7068785 & 2.217 & 2,5-Dimethylfuran-3,4(2H,5H)-dione \\
\hline 11 & 12.785 & 2498777 & 0.7837 & Mequinol \\
\hline 12 & 12.961 & 2563009 & 0.8038 & 1,4-Dioxane-2,6-dimethanol \\
\hline 13 & 14.726 & 3985785 & 1.2501 & Catechol \\
\hline 14 & 15.158 & 4746753 & 1.4887 & 5-Hydroxymethylfurfural \\
\hline 15 & 21.55 & 1466634 & 0.46 & Tetradecanoic acid \\
\hline 16 & 23.666 & 68435815 & 21.4635 & n-Hexadecanoic acid \\
\hline 17 & 25.335 & 1298483 & 40.7242 & 9,12-Octadecadienoic acid $(\mathrm{Z}, \mathrm{Z})$ \\
\hline 18 & 25.526 & 6101841 & 1.9137 & 9,12-Octadecadienoic acid (Z,Z) \\
\hline 19 & 27.027 & 6967951 & 2.1854 & Linoleic acid ethyl ester \\
\hline 20 & 28.447 & 8576883 & 2.69 & Hexadecanoic acid, 2-hydroxy-1-(hydroxymethyl)ethyl ester \\
\hline 21 & 29.831 & 13537452 & 4.2457 & 9,12-Octadecadienoic acid (Z,Z)-, 2,3-dihydroxypropyl ester \\
\hline 22 & 35.71 & 9578497 & 3.0041 & .gamma.-Sitosterol \\
\hline 23 & 35.937 & 1923203 & 0.6032 & 1,4-Bis(trimethylsilyl)benzene \\
\hline
\end{tabular}




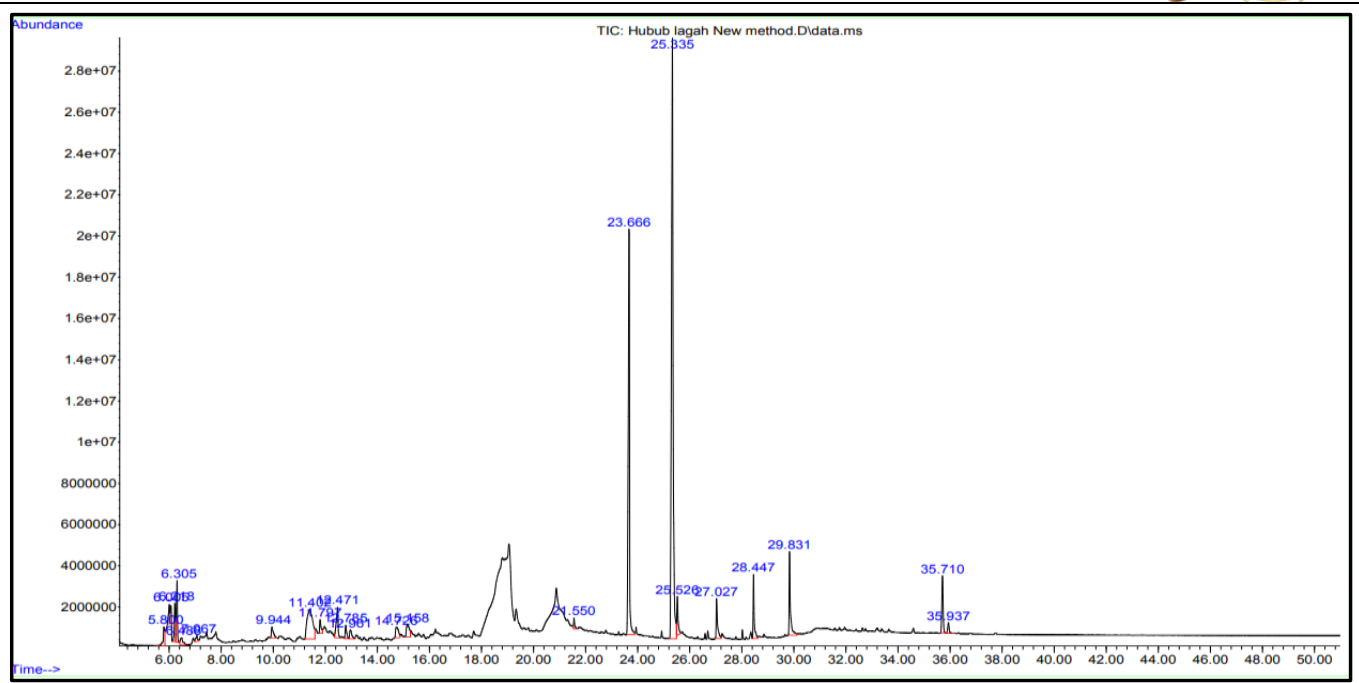

FIGURE 3. Active compounds present in the hexane extract.

- Metal Detection Using ICP-OES OPTIMA 8300 PERKINELMER ( Inductively Coupled Plasma Optical Emission Spectroscopy)

The results in Table 4 indicated a high percentage of calcium, where it reached after multiplication by dilution factor (20 Once) to $19.794 \mathrm{~g} / \mathrm{L}$, as well as a high percentage of potassium $23.620 \mathrm{~g} / \mathrm{L}$, while magnesium was $4.578 \mathrm{~g} / \mathrm{L}$ and zinc was $0.080 \mathrm{~g} / \mathrm{L}$. These results were the highest found by [20], this may be due to the soil quality and water environment of the Iraqi marshes rich in mineral elements. This gives a good indication of pollen from a nutritional point of view in providing the body of important metallic elements.

TABLE 4. Mineral elements in pollen typha domingensis.

\begin{tabular}{cc}
\hline Metallic Elements & Amount $\mathbf{g} / \mathbf{L}$ \\
\hline Arsenic (AS) & 0.005 \\
Calcium (Ca) & 19.794 \\
Cadmium $(\mathrm{Cd})$ & 0.0004 \\
Chromium $(\mathrm{Cr})$ & 0.002 \\
Copper $(\mathrm{Cu})$ & 0.007 \\
Iron $(\mathrm{Fe})$ & 0.086 \\
Magnesium $(\mathrm{Mg})$ & 4.578 \\
Manganese $(\mathrm{Mn})$ & 0.108 \\
Nickel $(\mathrm{Ni})$ & 0.005 \\
Potassium $(\mathrm{K})$ & 23.620 \\
Sodium $(\mathrm{Na})$ & 2.300 \\
Strontium $(\mathrm{Sr})$ & 0.037 \\
Zinc $(\mathrm{Zn})$ & 0.080 \\
\hline
\end{tabular}

\section{- Gluten Test}

The test Result showed that the gluten mass did not remain after washing and the paste melting with the washing water . This indicates that the flour is free of gluten and does not combine with more water. 


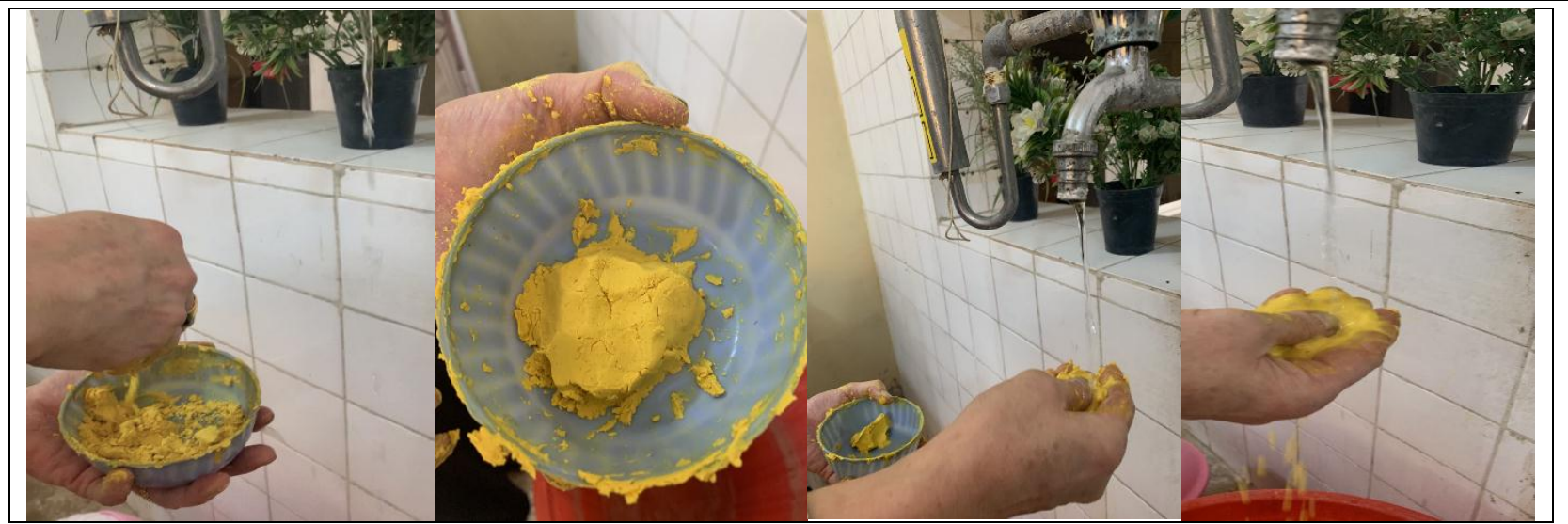

FIGURE 4. Stages of washing pollen paste under water.

\section{- Determination of The Amount of Flavonoids}

Natural antioxidants, especially flavonoids, are one of the most appropriate tradeoffs to avoid the consequences of oxidation and deterioration of food products when compared to industrial antioxidants and their health problems, in addition to forming a distinctive color imprint in the products included in their composition . On the other hand ,they enhance the nutritional value and health benefits [1,21]. Through the standard curve of rutin, the amount of flavonoids present in aqueous, ethanol, and hexane pollen extracts was calculated, as shown in the following figure 5 . The results in Figure 6 showed a clear convergence in the flavonoid content ranged between $95-99 \mathrm{mg} / \mathrm{ml}$ for the three extracts (ethanol, aqueous and hexane) at concentration 50 and $75 \mathrm{mg} / \mathrm{ml}$, as the ethanolic extract gave the highest content of flavonoids that reached 99 and $97 \mathrm{mg} / \mathrm{ml}$ at concentrations 75 and $50 \mathrm{mg} / \mathrm{ml}$. respectively, compared to the rest of the concentrations of the other extracts. While the aqueous extract recorded the highest concentration $(74,40,38) \mathrm{mg} / \mathrm{ml}$ at $25,12.5,8.5 \mathrm{mg} / \mathrm{ml} \mathrm{respectively}$, These results were approach what was reached [7], it was found that the total content of flavonoids for the pollen extract was $71.3 \mathrm{mg}$ total flavonoid in each $50 \mathrm{gm}$ of pollen.

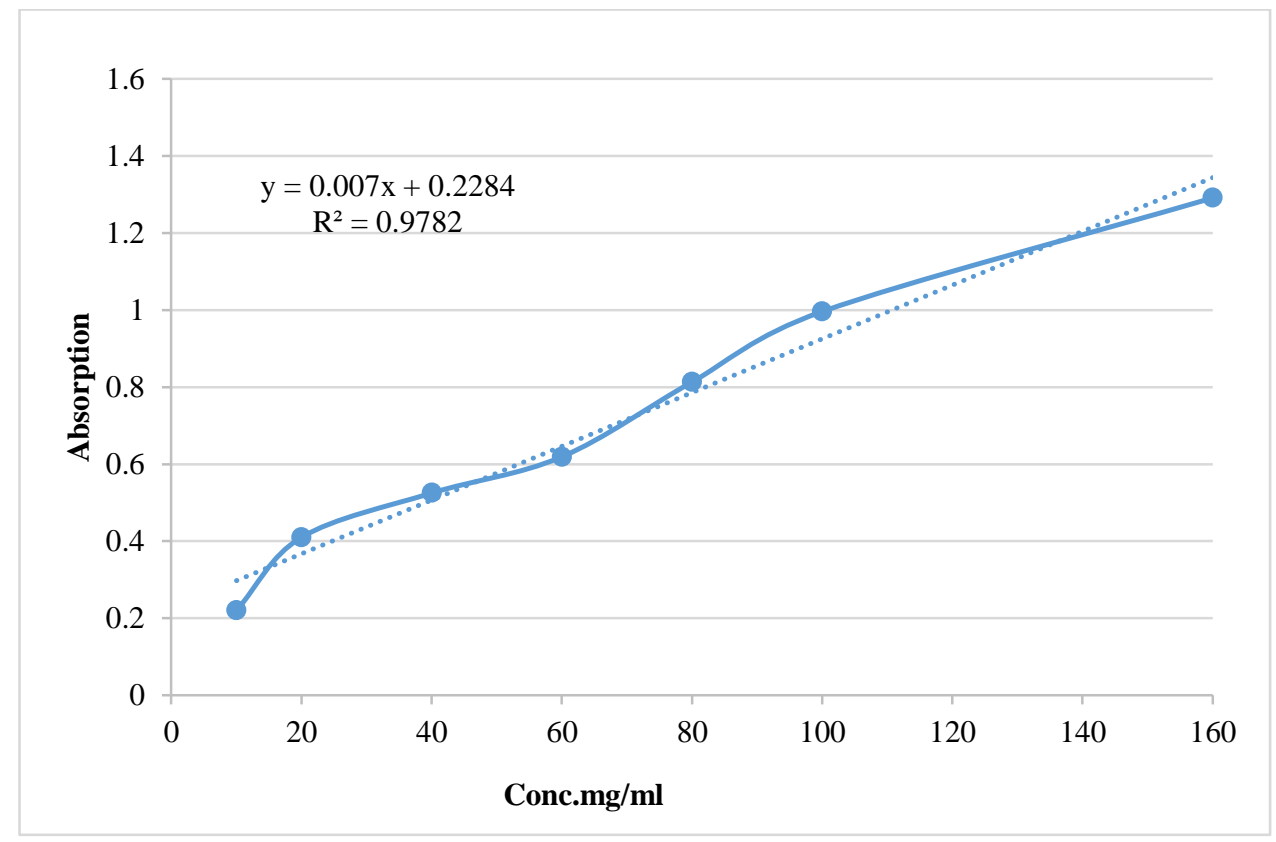

FIGURE 5. Standard curve of Rutin. 


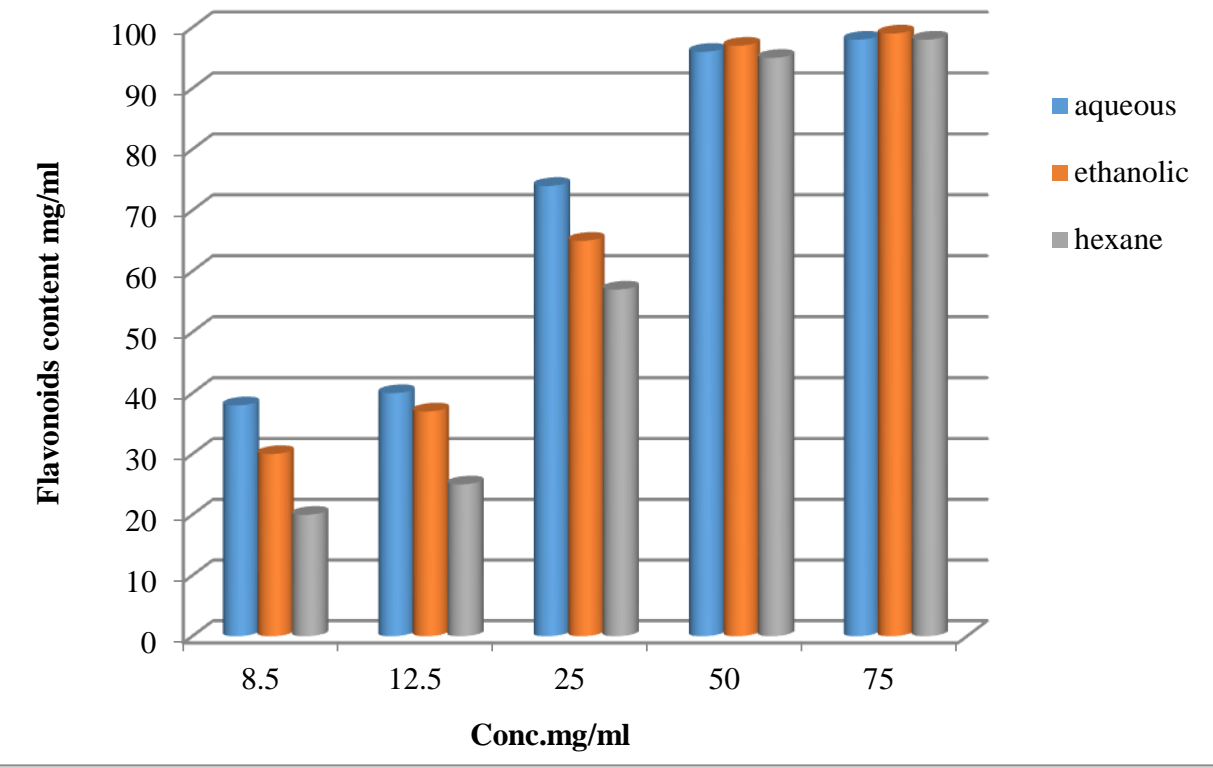

FIGURE 6. Flavonoids content of pollen extracts.

\section{- DPPH Radical Scavenging Assay}

The antioxidant activity of pollen was evaluated using DPPH reagent, which is an unstable free radical that is converted to diphenyl-1-picrylhydrazine-2,2 by reacting with the hydrogen -donated pollen extract .This led to the disappearance of the purple color and the formation of a yellow color and a decrease in the absorption value at 715 . Pollen extracts showed good inhibition of DPPH roots, this ability increased with increasing concentration. The highest percentage of DPPH inhibition was at $75 \mathrm{mg} / \mathrm{ml}(83,79$ and $76 \%$ ) for the extract (hexane, ethanol, and aqueous) respectively, while the concentration is 8.5 $\mathrm{mg} / \mathrm{ml}$, the lowest inhibition rate was $(60,55$ and 45$) \%$ for the extract (hexane, ethanol, and aqueous), respectively, This is consistent with what was indicated by [7] that pollen has the ability to inhibit DDPH radical of a percentage of $36.21 \%$ at a concentration of $250 \mu \mathrm{g} / \mathrm{ml}$.

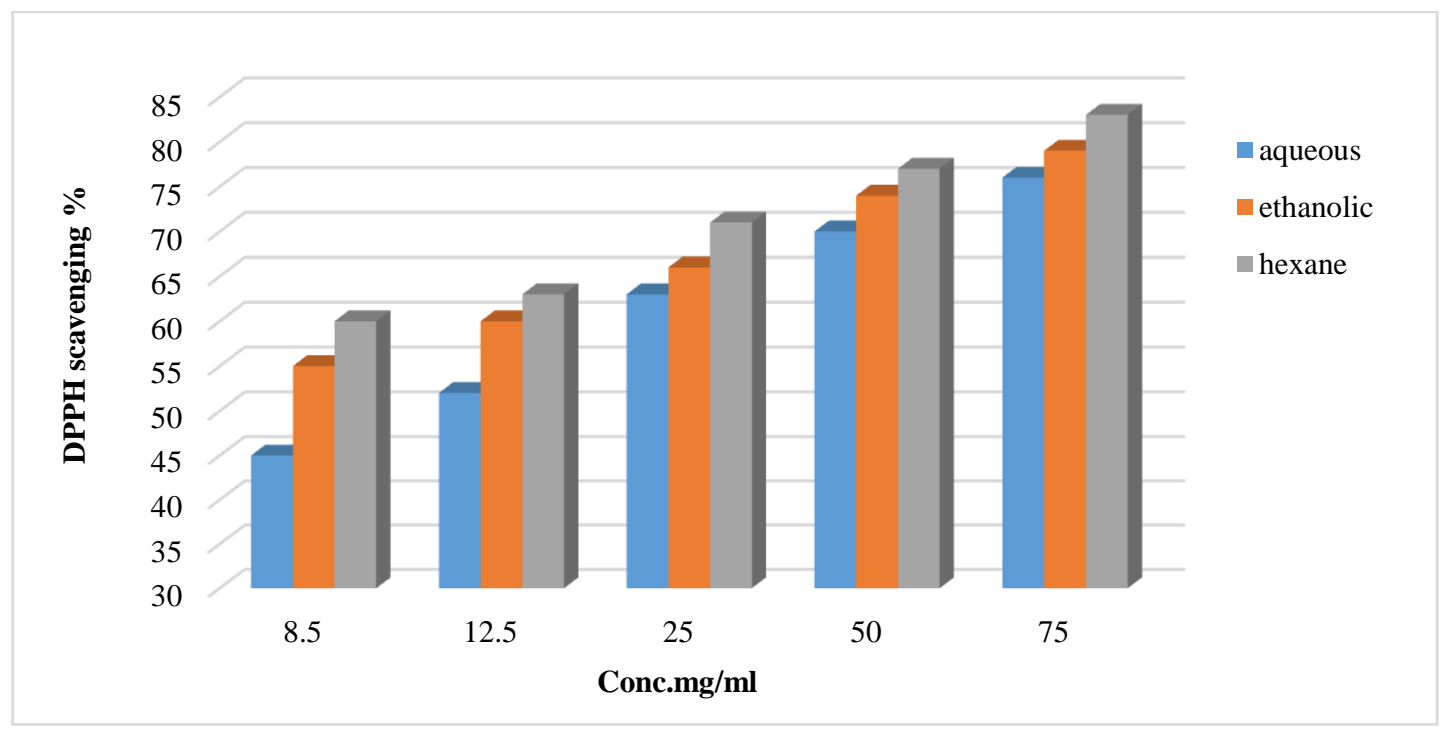

FIGURE 7. DPPH Scavenging by pollen extracts (aqueous, ethanol and hexane).

\section{- Manufacture of Pollen Cake}

Wheat flour was replaced by pollen flour at $50 \%$ for sample B and $75 \%$ for sample $\mathrm{C}$ when making the sponge cake. Compared with the pollen-free sample A, the sensory test results showed significant differences in the color trait of the samples under study where the sample B and C were distinguished by a golden color Unique compared to sample A, the 
sensory test results also showed unique characteristics of sample B and $\mathrm{C}$ in terms of odor and flavor with a significant difference from sample $\mathrm{A}$, the incorporation by $75 \%$ led to a significant decrease in the degree of cake cohesion and this is due to the lower percentage of Glutein in sample $\mathrm{C}$ compared to the rest of the sample. This is consistent with what was indicated by [22] that the partial replacement of wheat flour with avocado seed flour by $75 \%$ had a significant effect on the sensory properties of the processed cake, as it gave it a bitter taste, a fragrant smell, a somewhat rough texture and a brown color compared to the control sample.

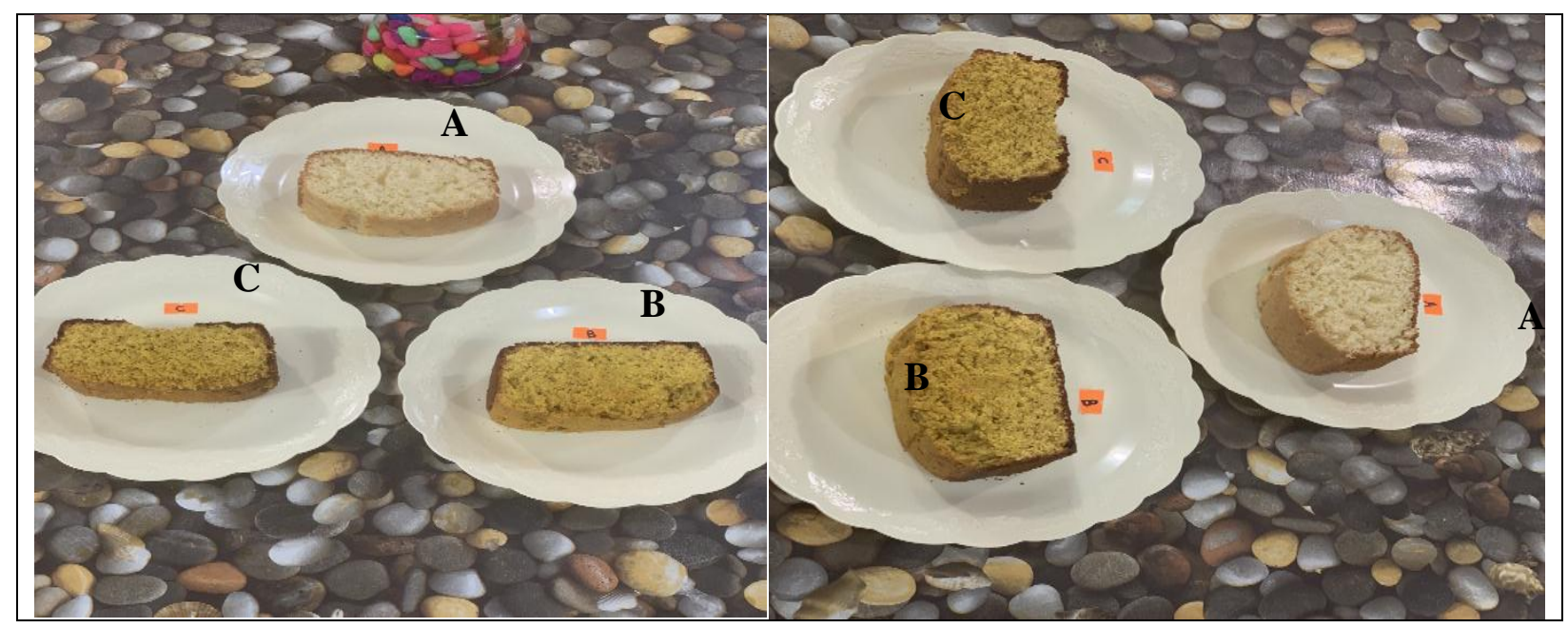

FIGURE 8. A/ pollen free cake , B / cake containing $50 \%$ of pollen $\quad, \mathrm{C} /$ cake containing $75 \%$ of pollen.

TABLE 5. Sensory evaluation form.

\begin{tabular}{ccccccc}
\hline Treatment & Color & Textures & Appearance & Odor & Taste & Total \\
\hline A & $13.3 \pm 0.55 \mathrm{~b}$ & $18.5 \pm 0.45 \mathrm{a}$ & $17.2 \pm 0.62 \mathrm{a}$ & $15.2 \pm 0.46 \mathrm{~b}$ & $17.5 \pm 0.47 \mathrm{~b}$ & $81.7 \pm 1.22 \mathrm{~b}$ \\
$\mathrm{~B}$ & $19.1 \pm 0.23 \mathrm{a}$ & $18.3 \pm 0.39 \mathrm{a}$ & $18.5 \pm 0.50 \mathrm{a}$ & $19.3 \pm 0.26 \mathrm{a}$ & $19.2 \pm 0.20 \mathrm{a}$ & $94.4 \pm 0.87 \mathrm{a}$ \\
$\mathrm{C}$ & $18.3 \pm 0.42 \mathrm{a}$ & $16.3 \pm 0.55 \mathrm{~b}$ & $17.7 \pm 0.47 \mathrm{a}$ & $13 \pm 0.29 \mathrm{c}$ & $14.1 \pm 0.37 \mathrm{c}$ & $79.4 \pm 0.88 \mathrm{~b}$ \\
\hline
\end{tabular}

\section{CONCLUSION}

Typha domingensis pers .pollen is an important food source that contains the most important antioxidant compounds and vital minerals important in enhancing the body's immunity, The available research that can be cited on this subject is very little. Pollen extracts are distinguished by their high content of bioactive compounds such as gamma .sitosterol, catechol, propionic acid, phenols, palmitoleic acid As well as its good content of flavonoids and minerals important for the human body, pollen extracts showed good inhibition of DPPH radicals, and this ability increased with increasing concentration. , With this research paper, we were able to conclude that it is possible to develop suitable cake mixes with low gluten content with up to $75 \%$ pollen to meet the needs of a range of people with gastrointestinal disorders or partial gluten sensitivity. Replacing wheat flour with pollen flour did not partially affect the spongy texture or appearance of the cake, especially on treatment B (50\% pollen cake) This is consistent with what was indicated by [23] that the partial replacement of wheat flour pearl with millet flour showed a significant change in the rheological properties compared with the control sample, But incorporation by $75 \%$ led to a significant decrease in the degree of cake cohesion and this is due to the lower percentage of gluten. From a functional point of view, the presence of pollen in cake ingredients gives it a longer shelf life due to the presence of antioxidant flavonoids that break the chain of reactions that cause fat oxidation and quality deterioration, so industrial antioxidants can reward in protection and delay food spoilage. Finally, more work needs to be done to evaluate the efficiency and bioavailability of the pollen extract in vivo.

\section{ACKNOWLEDGMENTS}

The authors would like to thanks Basrah University, the marsh research center marshes and Dr. Sabah Kadhum AlHummod for their support and assistance in carrying out this research. 


\section{REFERENCES}

[1] Al-Kalifawi , E. J., Al-Azzawi, Y. J. , Al-Fartousi , K. K. and Mezher, H. 2017. Physicochemical, phytochemical profiling and Biological activities of leaves extract of Bardy (Typha domingensis Pers.) from Al-Chibayish marshes in southern Iraq (pp. 128-143).

[2] Gomes, M. V. T., de Souza, R. R., Teles, V. S., \& Mendes, É. A. 2014. Phytoremediation of water contaminated with mercury using Typha domingensis in constructed wetland. Chemosphere, 103, 228-233.

[3] Hegazy, A. K., Abdel-Ghani, N. T., \& El-Chaghaby, G. A. 2011. Phytoremediation of industrial wastewater potentiality by Typha domingensis. International Journal of Environmental Science \& Technology, 8(3), 639-648.

[4] Heli, H., Mirtorabi, S., \& Karimian, K. 2011. Advances in iron chelation: an update. Expert opinion on therapeutic patents, 21(6), 819-856.

[5] Tundis, R., Loizzo, M. R., \& Menichini, F. 2010. Natural products as $\alpha$-amylase and $\alpha$-glucosidase inhibitors and their hypoglycaemic potential in the treatment of diabetes: an update. Mini reviews in medicinal chemistry, 10(4), 315-331.

[6] Liu, H., Mou, Y., Zhao, J., Wang, J., Zhou, L., Wang, M., ... Yang, F. 2010. Flavonoids from Halostachys caspica and their antimicrobial and antioxidant activities. Molecules, 15(11), 7933-7945.

[7] Karbon, M. H., Azeez, R. J., Mohammed, Z. Y., \& Hasan, A. N. Y. 2019. Phytochemical properties and antioxidant activity of pollen typha domingenisis pers . grown marshes of maysan governorate southern of Iraq. Journal of Global Pharma Technology, 11(9), 564-570.

[8] Smith, S. G. 2000. Titleyphaceae. In: Flora of North America Editorial Committee (eds.), Flora of North America. vol. 22. Oxford University Press, New York-Oxford:278-285. http://www.efloras.org/florataxon.aspx?flora_id=1\&taxon_id=134063.

[9] Lakshmi, K. S., Sailaja, V. H., \& Reddy, M. A. 2017. Phytoremediation-a promising technique in waste water treatment. International Journal of Scientific Research and Management (IJSRM), 5(06), 5480-5489.

[10] Morton, J. F. 1975. Cattails (Typha spp.) —weed problem or potential crop. Economic Botany, 29(1), 7-29.

[11] Gomes, L. de O. F., Santiago, R. de A. C., Carvalho, A. V., Carvalho, R. N., Oliveira, I. G. de, \& Bassinello, P. Z. 2015. Application of extruded broken bean flour for formulation of gluten-free cake blends. Food Science and Technology, 35, 307-313.

[12] Conte, P., Del Caro, A., Balestra, F., Piga, A., \& Fadda, C. 2018. Bee pollen as a functional ingredient in gluten-free bread: A physical-chemical, technological and sensory approach. LWT, 90, 1-7.

[13] de Florio Almeida, J., dos Reis, A. S., Heldt, L. F. S., Pereira, D., Bianchin, M., de Moura, C., ... da Luz, C. F. P. 2017. Lyophilized bee pollen extract: A natural antioxidant source to prevent lipid oxidation in refrigerated sausages. LWT-Food Science and Technology, 76, 299-305.

[14] ASTM, D. (1976). 07 2007. Standard Test Method for Elements in Water by Inductively-Coupled Argon Plasma Atomic Emission Spectroscopy. West Conshohocken, PA, DOI: 10.1520/D1976-07.

[15] PN-77/A-74041. 1977. Ziarno zbóż i przetwory zbożowe - Oznaczanie ilości i jakości glutenu. Polski Komitet Normalizacyjny, Warsaw, Poland.

[16] Djeridane, A., Yousfi, M., Nadjemi, B., Boutassouna, D., Stocker, P., \& Vidal, N. 2006. Antioxidant activity of some Algerian medicinal plants extracts containing phenolic compounds. Food chemistry, 97(4), 654-660.

[17] El-Baky, H. H. A., El Baz, F. K., \& El-Baroty, G. S. 2009. Production of phenolic compounds from Spirulina maxima microalgae and its protective effects. African Journal of Biotechnology, 8(24), 7059-7067.

[18] Brand-Williams, W., Cuvelier, M.-E., \& Berset, C. 1995. Use of a free radical method to evaluate antioxidant activity. LWTFood science and Technology, 28(1), 25-30.

[19] A.A.C.C. 2002. Approved Method of American Association of Cereal Chemists, published by American Association of Cereal Chemists, Ins. St.Paul, Minnesota, USA.

[20] Charpentier, M. 1996. Comer del monte: volver amis, o un paso adelante. Cuadernos Agroforestales 1. Productos Forestales No Madereros. Desarrollo Agroforestal y Comunidad Campesina 20:59-66.

[21] Aljazy, N. A. S. \& Abdulstar, A. R. 2021. Potential Effects Of Natural Antioxidants In The Treatment Of Some Viral Diseases : Review. Al-Qadisiyah Journal For Agriculture Sciences (QJAS), 11(2).

[22] Puspitasari, M., Hasri, R. N., \& Wahyuni, T. 2021. The Substitution of Avocado Seed Flour to Rice Flour in the Manufacture of Traditional Palembang Food Gandus Cake. In First International Conference on Health, Social Sciences and Technology (ICOHSST 2020) (pp. 37-40).

[23] El Tanahy, H. H., Sharoba, A. M., Ghazal, G. A., Abd Elmola, E. M., \& Zamzam, E. H. 2021. Improve the Nutritive Value of Produced Cake by Replacement Wheat Flour with Pearl Millet Flour. Food Biotechnology, 445-454 